\title{
Phytotoxicity of amidosulfuron (sulfonylu- reas herbicide) to aquatic macrophyte Lemna minor L.
}

Jūratė Žaltauskaitè $\dot{x}^{*}$

\section{Roberta Norvilaitè}

Vytautas Magnus University,

Vileikos 8,

LT-44404 Kaunas,

Lithuania
This study examines effects of sulfonylurea herbicide Sekator OD 375 (amidosulfuron and iodosulfuron) to non-target aquatic plant species common duckweed (Lemna minor L.). The plants were affected by $5-75 \mu \mathrm{l} / \mathrm{l}$ concentrations of herbicide in their growth medium. L. minor had a strong phytotoxicty response to herbicide application (inhibition of growth, biomass, reduced content of photosynthetic pigments and increased content of malondialdehyde). The growth rate of $L$. minor was inhibited by $54.17 \%$. The dry biomass was by $57.2 \%$ lower than in control. Application of herbicide provoked an oxidative stress, the concentrations of MDA was by $83.32 \%$ higher than in control.

Key words: herbicides, non-target aquatic plant, oxidative stress, phytotoxicity

\section{INTRODUCTION}

The usage of herbicides has been increasing worldwide and poses a potential human health and ecological risk. Herbicides affect not only the

* Corresponding author. E-mail: j.zaltauskaite@gmf.vdu.lt species of plants they are used to destroy (targeted ones), but also not-targeted ones. Previously it has been shown that herbicides may evoke deleterious effects to crop and non-crop species (Wang, Zhou, 2006; Riemens et al., 2008). Herbicide agricultural application usually leads to contamination of 
adjacent water bodies. Low herbicide levels usually are observed in surface waters and they enter water bodies via spray drift, leaching and surface runoff (Battaglin et al., 2000; KöckSchulmeyer et al., 2012).

The primary targets of herbicide action in water ecosystems are phytoplankton and plants. The phytotoxicity of various herbicides has been shown in several studies (Peterson et al., 1994; Olette et al., 2008). In aquatic ecosystems aquatic plants have an important role in the food chain since they are primary producers; they provide food and shelter for other aquatic organisms. Adverse herbicide impact on aquatic plants may disturb community structure, reduce biodiversity and alter ecosystems functions, especially nutrient cycling and energy flow.

Duckweeds are a widespread, fast-growing free-floating macrophytes and Lemna spp. are among the most popular standardised aquatic test organisms in toxicity testing. Moreover, it is one of the effective phytoremediation agents used for contaminated water bodies remediation, wastewater treatment (Mkandawire, Dudel, 2007). Common duckweed (Lemna minor L.) was shown to be sensitive to various inorganic (Horvat et al., 2007) and organic compounds such as herbicides (Teodorović, 2012; Wilson, Koch, 2013).

The use of sulfonylureas is increasing since their discovery in the 1970's due to their relatively low toxicity to animals and very low application level. Sulfonylurea herbicides are strong acetolactate synthase (ALS) inhibitors. ALS is the first common enzyme of branchedchain amino acid (valine, leucine and isoleucine) biosynthesis. Amidosulfuron is recommended for use on wheat (winter and spring) and spring barley for the control of broad-leaved weeds. The mechanism of sulfonylureas action and toxicity to higher terrestrial plants is well studied (Duke, 1990; Kudsk, Mathiassen, 2004; Binder et al., 2007), although relatively little is known about the toxic effects of these herbicides on non-target aquatic organisms. Several studies have shown that sulfonylurea herbicides negatively affect growth, physiology and reproduction of non-target aquatic plant (Frankart et al., 2003; Eullaffroy et al., 2007; Fairchild et al., 2007). The aim of the study was to evaluate the sulfonylurea herbicide effects to non-target aquatic plant species common duckweed (Lemna minor L.) physiology (content of photosynthetic pigments) and growth (biomass and growth rate) and to determine whether amidosulfuron could induce oxidative stress.

\section{MATERIALS AND METHODS}

Common duckweed was obtained from Vytautas Magnus University laboratory stock culture grown from the plants originally collected in Kaunas Botanical Garden. The plants were exposed to $5,10,25,50,75 \mu \mathrm{l} / \mathrm{l}$ of commercially available Sekator OD 375 (Bayer CropScience). Sekator OD 375 is composed of amidosulfuron (9\%), iodosulfuron methyl, sodium salt (2.2\%) and mephenpyr diethyl (22\%). Herbicide was dissolved in growth medium of L. minor.

The growth inhibition test with $L$. minor was performed according to modified OECD Guideline 221 (2004). The stock culture of L. minor was grown in modified Steinberg medium (ISO 20079) at $24{ }^{\circ} \mathrm{C} \pm 2{ }^{\circ} \mathrm{C}$ with a light:dark cycle of 16:8 h. 40 double-fronded healthy $L$. minor colonies were transferred to glass beakers containing different concentrations of herbicide in Steinberg growth medium. The experiment was conducted in growth chambers at $24^{\circ} \mathrm{C} \pm 2{ }^{\circ} \mathrm{C}$ with a light:dark cycle of $16: 8 \mathrm{~h}$. The experiment lasted 7 days and was conducted in 3 replicates.

Toxicity was recorded as percent inhibition of growth (fronds number), dry weight, content of photosynthetic pigments (chlorophyll a, b and carotenoids), and content of malondialdehyde. Fronds number was scored every day and all visible fronds were counted. Specific growth rate was calculated from the following equation with measured fronds number $(\mathrm{N})$ at day $\mathrm{t}_{1}$ and at day $\mathrm{t}_{0}$ :

$$
r=\frac{\ln \left(N_{t_{1}}\right)-\ln \left(N_{t_{0}}\right)}{\mathrm{t}_{1}-\mathrm{t}_{0}}
$$


For dry weight assessment, the plants were dried at $60^{\circ} \mathrm{C}$ for $48 \mathrm{~h}$ up to constant weight.

Content of photosynthetic pigments (chlorophyll a, b and carotenoids) was measured spectrophotometrically (DU 800 "Beckman Coulter") in $100 \%$ acetone extract (0.045$0.094 \mathrm{~g}$ ) plant tissue (Von Wettstein, 1957). Concentration of malondialdehyde (MDA), the by-product of lipid peroxidation, was used as biomarker of membrane oxidative damage. MDA content was determined by reaction with thiobarbituric acid (TBA) (Buege, Aust, 1978).

A one-way analysis of variance (ANOVA) was used to assess the concentration effect on estimated endpoints. Significant differences between control and samples, treated with herbicide, were determined by the Student's t-test and were considered to be significant at $\mathrm{p}<0.05$. Effective concentration (EC) values were calculated using logistic dose-response model (Ritz, Streibig, 2005). Regression analysis was used to detect the relationship between herbicide concentration and estimated parameters. The statistical analysis was carried out using $\mathrm{R}$ version 2.15.2 ( $\mathrm{R}$ Development Core Team, 2004) and Statistica software.

\section{RESULTS}

In order to investigate the fronds production dynamics during the 7-day treatment with amidosulfuron, relative day-to-day growth rate (across all concentrations) every day in comparison with the previous days, i. e. every $24 \mathrm{~h}$, was calculated (Fig. 1). The highest growth rate was recorded between 24 and $48 \mathrm{~h}$ and this phenomenon was observed in all treatments, though this increase in comparison with the growth rate $0-24 \mathrm{~h}$ was statistically insignificant at all concentrations ( $p>0.05$ ). One-way ANOVA showed that after $24 \mathrm{~h}$ of treatment the concentrations of amidosulfuron had no significant effect on the growth rate $(\mathrm{F}=3.06, \mathrm{p}=0.052)$ and only in case of the highest concentration $\left(75 \mu \mathrm{l} \mathrm{l}^{-1}\right)$ the growth rate was significantly lower (by 51\%) than that of control plants (t-test, $\mathrm{p}=0.04$ ). The day-to-day growth rate in the period between $48 \mathrm{~h}$ and $144 \mathrm{~h}$ of exposure was significantly affected by the concentration of amidosulfuron in the medium $(\mathrm{F}>3.29, \mathrm{p}<0.05)$. Regression analysis revealed that in the period $48-144 \mathrm{~h}$ the growth rate decreased along with the

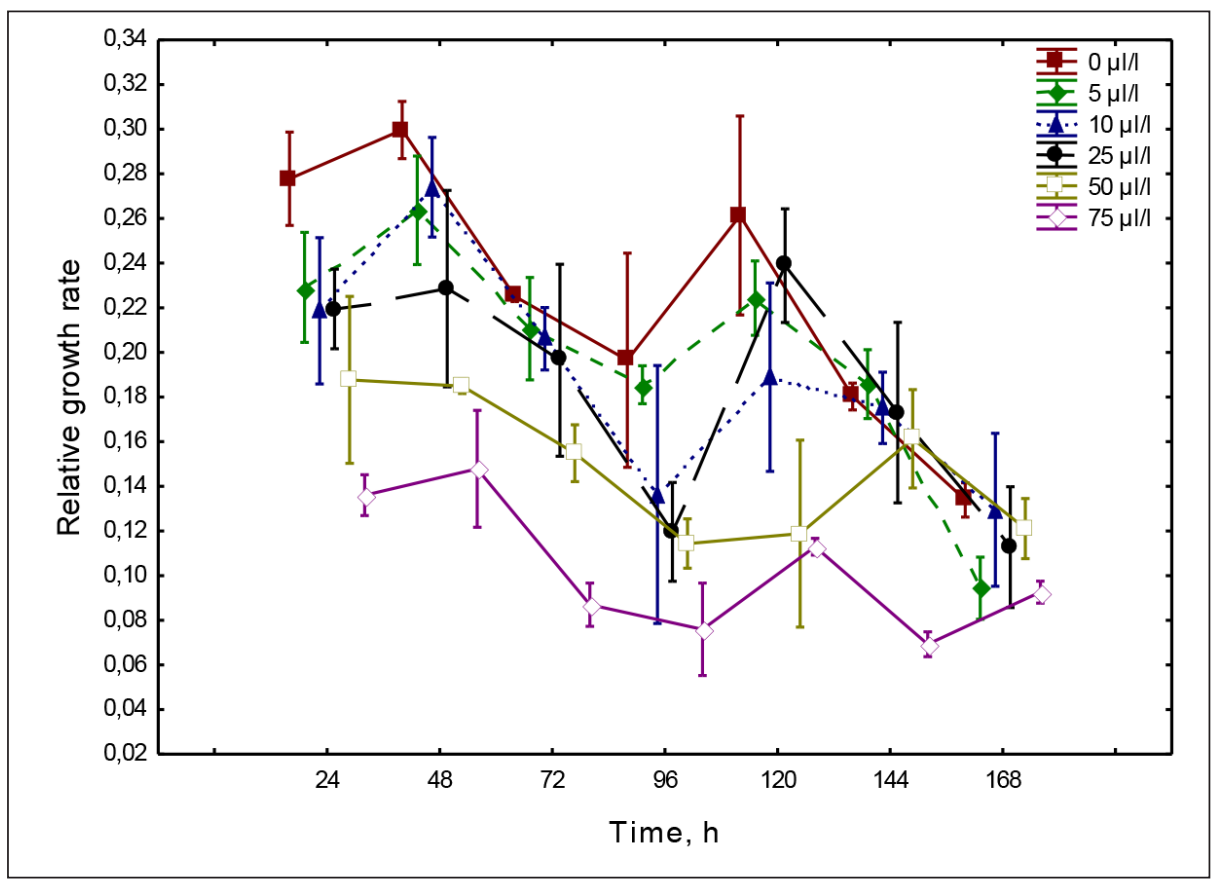

Fig. 1. The growth rate (at 24 h intervals) of $L$. minor exposed to different concentrations of herbicide amidosulfuron 
concentration of amidosulfuron $\left(\mathrm{R}^{2}>0.44\right.$, $\mathrm{p}<0.01)$. Although at the end of the experiment (144-168 h), the growth rate was not affected by the concentration $(\mathrm{F}=0.7, \mathrm{p}=0.63)$. During the last $24 \mathrm{~h}$ of the experiment the growth rate was significantly lower (by 34.54-64.20\%) than that during 24-48 h, with exception of the treatment with the highest concentration $\left(75 \mu \mathrm{l} \mathrm{l}^{-1}\right)$. Regression analysis revealed that when $L$. minor was exposed to amidosulfuron day-to-day growth rate decreased along with time $\left(\mathrm{R}^{2}>0.18, \mathrm{p}<0.05\right)$. The effect of time was more pronounced in the treatments with low (5-10 $\left.\mathrm{Ll}^{-1}\right)$ concentrations of amidosulfuron.

Relative growth rate of $L$. minor during the whole 7-day exposure period was significantly affected by amidosulfuron $(\mathrm{F}=37.85, \mathrm{p}<0.01)$ (Fig. 2). Exposure to $5 \mu \mathrm{l} \mathrm{l}^{-1}$ of amidosulfuron led to a decrease of growth rate by $11.5 \%$ in comparison with control plants $(\mathrm{p}<0.05)$. Further increase in herbicide concentration up to $25 \mu \mathrm{l} / \mathrm{l}$ resulted in very small decrease (by $7.51 \%)$ in relative growth rate compared with the growth rate at $5 \mu \mathrm{l} \mathrm{l}^{-1}$. A more pronounced relative growth rate reduction was observed in treatments with $25-75 \mu \mathrm{ll}^{-1}$ of amidosulfuron and at $75 \mu \mathrm{l}^{-1}$ the growth rate was decreased by $54.17 \%$ in comparison with control. The regression analysis showed that $L$. minor 7 -day relative growth rate significantly decreased with herbicide concentration in medium $\left(\mathrm{R}^{2}=0.90\right.$, $\mathrm{p}<0.01)$. Calculated $\mathrm{EC}_{20}$, effective concentration resulting in relative growth rate reduction by $20 \%$, was $34.03 \pm 5.29 \mu \mathrm{l} \mathrm{l}^{-1}$.

There was a highly significant effect of amidosulfuron concentration on L. minor dry weight after 7 days $(\mathrm{F}=109.91, \mathrm{p}<0.0001)$ (Fig. 3). L. minor exposed to the lowest herbicide concentrations $\left(5-10 \mu \mathrm{l} \mathrm{l}^{-1}\right)$ biomass reduction was very negligible $(0.8$ and $6.5 \%$, respectively) and statistically insignificant in comparison with control plants. Further increase in herbicide concentration led to a significant decrease of $L$. minor biomass. L. minor dry biomass decreased along with herbicide concentration $\left(\mathrm{R}^{2}=0.96, \mathrm{p}<0.001\right)$ and the treatment with $75 \mu \mathrm{ll}^{-1}$ resulted in $57.2 \%$ lower L. minor biomass than that of control plants. Calculated $\mathrm{EC}_{20}$, effective concentration resulting in reduction of biomass by $20 \%$, was $26.04 \pm 3.77 \mu \mathrm{l} \mathrm{l}^{-1}$.

A significant adverse impact on the content of photosynthetic pigments was observed (ANOVA, chlorophyll $a \mathrm{~F}=19.57$, chlorophyll

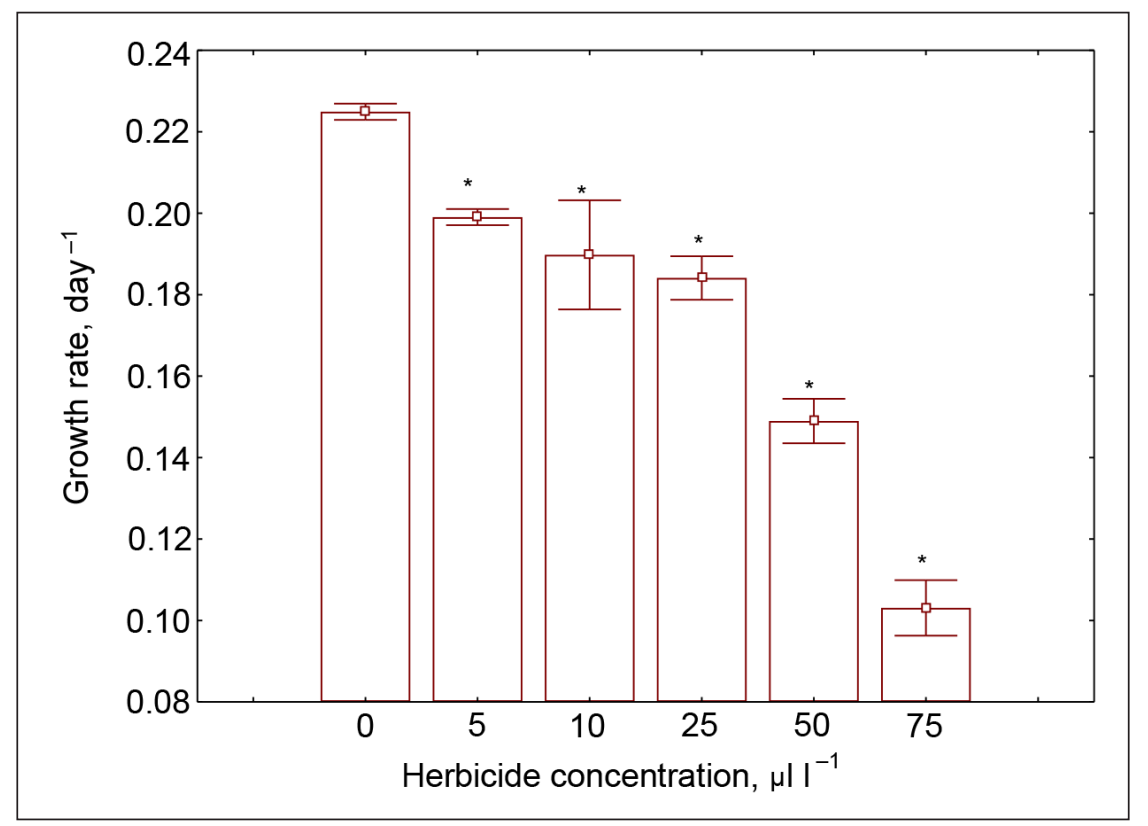

Fig. 2. Relative growth rate of L. minor exposed to different concentrations of herbicide amidosulfuron 


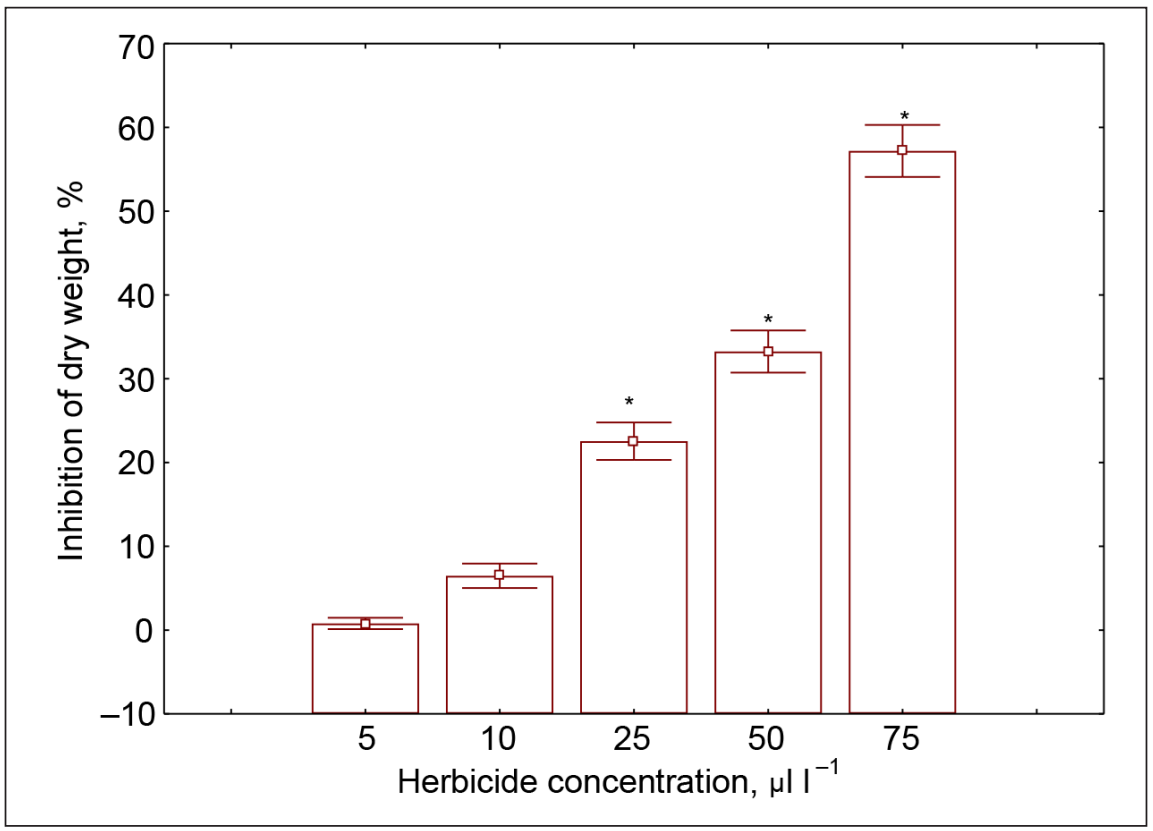

Fig. 3. Inhibition of dry weight of $L$. minor exposed to different concentrations of herbicide amidosulfuron

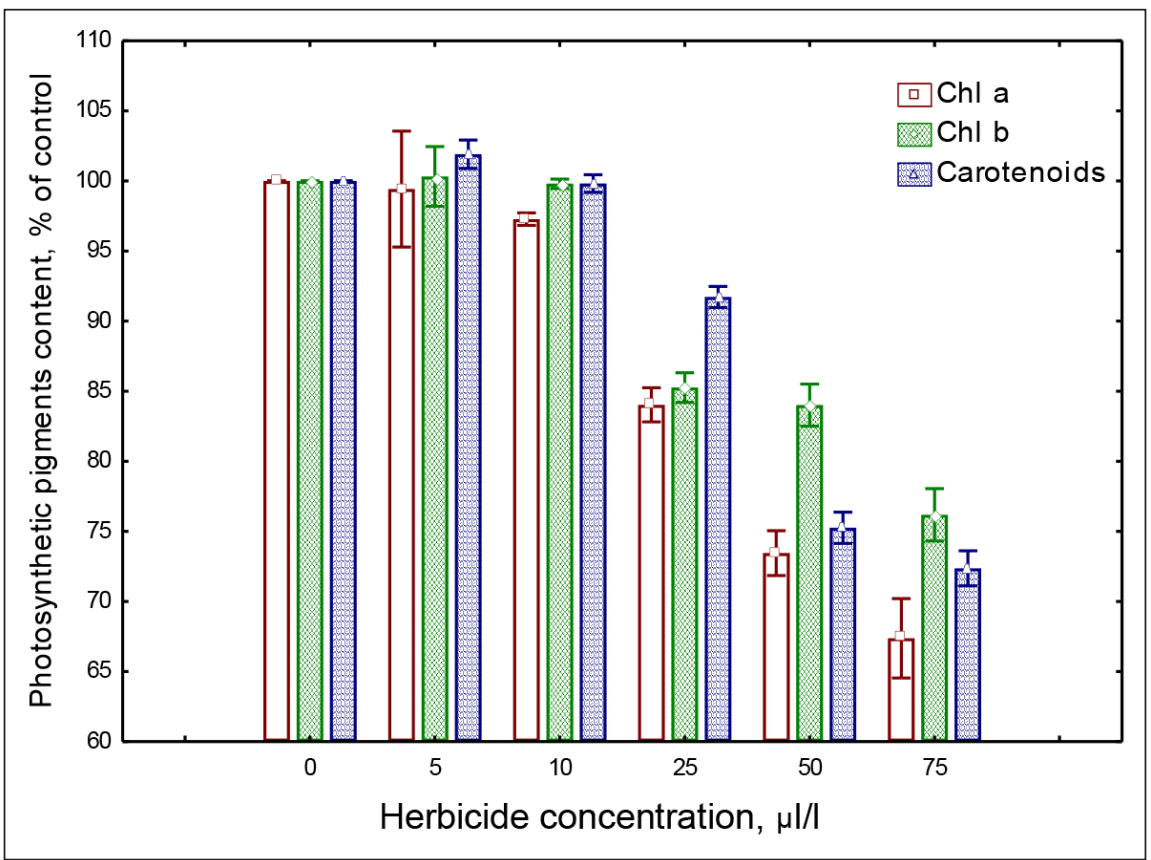

Fig. 4. Content of photosynthetic pigment in L. minor exposed to different concentrations of herbicide amidosulfuron

$b \mathrm{~F}=8.76$, carotenoids $\mathrm{F}=28.91, \mathrm{p}<0.01)$. The low concentrations $\left(5-10 \mu \mathrm{l} \mathrm{l}^{-1}\right)$ of herbicide caused very negligible and insignificant changes in photosynthetic pigment content compared with the control plants (Fig. 4). In the leaves of $L$. minor exposed to 25-75 $\mu \mathrm{l} \mathrm{l}^{-1}$ herbicide content of chlorophyll $a$ dropped by $15.97-32.63 \%$, chlorophyll $b$ by $14.74-23.81 \%$ and carotenoids by $8.27-27.64 \%$ compared with control $(\mathrm{p}<0.05)$. Multiple regression analysis showed that content of photosynthetic pigments decreased with the concentration 


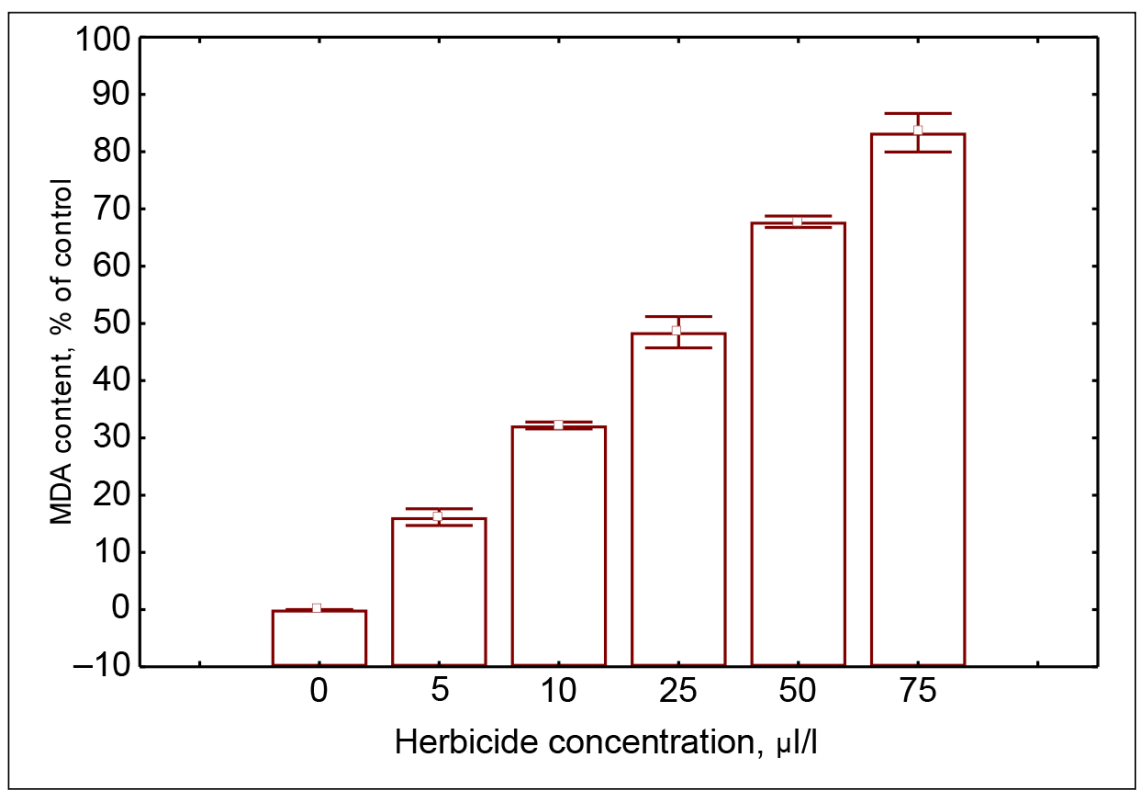

Fig. 5. MDA content in L. minor exposed to different concentrations of herbicide amidosulfuron

of herbicide (Chl $a \mathrm{R}^{2}=0.85$, Chl $b \mathrm{R}^{2}=0.70$, carotenoids $\left.\mathrm{R}^{2}=0.87, \mathrm{p}<0.001\right)$.

Lipid peroxidation is a sensitive measure of oxidative damage and is useful as a biomarker for oxidative stress. MDA content in plants increased from $16.16 \%$ to $83.32 \%$ with increasing concentrations of herbicide $\left(\mathrm{R}^{2}=0.93, \mathrm{p}<0.05\right)$ (Fig. 5).

\section{DISCUSSION}

L. minor is a monocot and it is likely that sulfonylureas used for control of dicot species in monocot crops should not exhibit high toxicity to $L$. minor, however, the study revealed that L. minor demonstrated high sensitivity to amidosulfuron.

Amidosulfuron induced a significant inhibition of relative growth rate with 7 -day $\mathrm{EC}_{20}$ of $34.03 \pm 5.29 \mu \mathrm{l} \mathrm{l} \mathrm{l}^{-1}$. The results of toxicity are in good agreement with literature data (Peterson et al., 1994; Davies et al., 2003; Aida et al., 2004; Fairchild et al., 2007). Mohammad et al. (2008) compared the toxicity of herbicides from several chemical classes and observed that sulfonylureas exhibited the highest toxicity to Lemna sp. in comparison with triazines, ureas, etc. Exposure to metsulfuron- methyl drastically reduced the relative growth rate of $L$. minor and $L$. minor showed the highest susceptibility to this herbicide among 12 tested aquatic submerged plant species (Cedergreen et al., 2004). On the other hand, L. minor exhibited lower susceptibility to bensulfuron methyl than other aquatic plants (Aida et al., 2004). However, these studies analysed only the growth rate during the whole 7-day period and did not analyse the growth dynamics day-by-day of this macrophyte.

The day-to-day growth rate analysis revealed that growth rate significantly varied during the study. The highest growth rate was recorded between 24 and $48 \mathrm{~h}$ and this phenomenon was observed in all treatments. Though this increase in comparison with the growth rate $0-24 \mathrm{~h}$ was statistically insignificant at all concentrations $(p>0.05)$. This tendency of higher growth rate during the second day of exposure may be explained by the fact that during the first day $L$. minor acclimatized to new conditions and started to grow, though only minor amounts of herbicide were absorbed by the plant. With time of exposure the herbicide was more absorbed by the plants and the growth rate declined; though the effect of time was more pronounced in the treatments with low (5- 
$10 \mu \mathrm{l}^{-1}$ ) concentrations of amidosulfuron than in those with the highest concentrations. It may be due to dramatic decrease of growth rate at the very beginning of exposure to high concentrations.

Amidosulfuron reduced the dry weight of L. minor and dry weight reduced as a function of herbicide concentration in the test medium $\left(\mathrm{R}^{2}=0.96, \mathrm{p}<0.001\right)$. Plant dry weight reduction due to herbicide has been also reported in other studies (Cedergreen et al., 2004; Cheshier et al., 2011). Dry weight was more sensitive $\left(\mathrm{EC}_{20}=26.04 \pm 3.77 \mu \mathrm{l} / \mathrm{l}\right)$ to herbicide application than growth rate. As in calculation of growth rate, any new visible daughter frond is counted, so under stress conditions very small fronds may be protruded and frond number may underestimate the toxic effect on duckweed. Due to this disadvantage, the biomass evaluation may be more suitable for toxicity assessment (Mohan and Hosetti 1999).

Despite the fact that sulfonylureas act as ALS inhibitors, a significant adverse impact on photosystem was also observed. The content of photosynthetic pigments decreased along with the concentration of amidosulfuron. Chlorophyll $a$ was the most sensitive among the analysed pigments. The response of chlorophyll $b$ and carotenoids was similar but less pronounced. The reduction of chlorophyll content due to plants exposure to herbicides was reported in numerous studies (Turgut et al., 2003; Geoffroy et al., 2004; Olette et al., 2008).

Amidosulfuron was shown to produce lipid peroxidation in the tissues of L. minor. A significant increase in MDA level (1.8-fold) indicates the presence of harmful active oxygen species and oxidative stress, which may result in reduction of growth, productivity or may cause the death of plants. Sulfonylureas have been shown to evoke oxidative stress in terrestrial plants: Hordeum vulgare and Chenopodium album (Žaltauskaitè, Brazaitytè, 2013), in Triticum aestivum (Wang, Zhou, 2006). Lipid peroxidation due to sulfonylureas application has not been studied and we cannot compare our results with other studies. Increased MDA content was recorded after L. gibba treatment with phenoxy herbicide quizalofop-p-ethyl (Doganlar, 2012).

\section{CONCLUSIONS}

The study revealed that herbicides cause adverse effects not only in target vegetation, but in non-target aquatic species as well. The herbicide application reduced the growth rate and dry weight of $L$. minor, altered the content of photosynthetic pigments and evoked oxidative stress. The growth rate was reduced by $54.17 \%$ and dry weight by $57.2 \%$. Our results suggest that herbicides runoff in drainage systems and rivers or even herbicide drifting away from the sprayed fields could have an adverse effect on the growth of aquatic plants and this in turn may affect the community structure and functions.

Received 25 May 2013

Accepted 20 June 2013

\section{References}

1. Aida M, Itoh K, Ikeda H, Harada N, Ishii Y, Usui K. Susceptibilities of some aquatic ferns to paddy herbicide bensulfuron methyl. Weed Biol Manag 2004; 4: 127-35.

2. Battaglin WA, Furlong ET, Burkhardt MR, Peter CJ. Occurrence of sulfonylureas, sulfonamide, imidazolinone, and other herbicides in privers, reservoirs and ground water in the Midwestern United States, 1998. Sci Total Envir 2000; 248: 123-33.

3. Binder S, Knill T, Schuster J. Branched-chain amino acid metabolism in higher plants. Phys Plant 2007; 129: 68-78.

4. Buege JA, Aust SD. Microsomal lipid peroxidation. Meth Enzym 1978; 52: 302-10.

5. Cedergreen N, Streibig JC, Spliid NH. Sensitivity of aquatic plants to the herbicide metsulfuron-methyl. Ecotox Envir Safety 2004; 57: 153-61. 
6. Cheshier JC, Wersal RM, Madsen JD. The susceptibility of duckweed (Lemna minor L.) to fluridone and penoxsulam. J Aquat Plant Manag 2011; 49: 50-2.

7. Davies J, Honegger JL, Tencalla FG, Meregalli G, Brain P, Newman JR, Pitchford HF. Herbicide risk assessment for non-target aquatic plants: sulfosulfuron - a case study. Pest Manag Sci 2003; 59: 231-7.

8. Doganlar ZB. Quizalofop-p-ethyl-induced phytotoxicity and genotoxicity in Lemna minor and Lemna gibba. J Envir Sci Health 2012; 47: 1631-43.

9. Duke SO. Overview of herbicide mechanisms of action. Env Health Persp 1990; 87: 263-71.

10. Eullaffroy P, Frankart C, Biagianti S. Toxic effect assessment of pollutant mixtures in Lemna minor by using polyphasic fluorescence kinetics. Toxic Envir Chem 2007; 89: 683-96.

11. Fairchild JF, Ruessler DS, Haverland PS, Carlson AR. Comparative Sensitivity of Selenastrum capricornutum and Lemna minor to Sixteen Herbicides. Arch Envir Contam Toxicol 1997; 32: 353-7.

12. Frankart C, Eullaffroy P, Vernet G. Comparative effects of four herbicides on non-photochemical fluorescence quenching in Lemna minor. Envir Exp Bot 2003; 49: 159-68.

13. Geoffroy L, Frankart C, Eullaffroy P. Comparison of different physiological parameter responses in Lemna minor and Scenedesmus obliquus exposed to herbicide flumioxazin. Envir Poll 2004; 131: 233-41.

14. Horvat $\mathrm{T}$, Vidaković-Cifrek $\check{Z}$, Oreščanin $\mathrm{V}$, Tkalec M, Pevalek-Kozlina B. Toxicity assessment of heavy metal mixtures by Lemna minor L. Sci Total Envir 2007; 384: 229-38.

15. Köck-Schulmeyer M, Ginebreda A, González S, Cortina JL, Lópes de Alda M, Barceló D. Analysis of the occurrence and risk assessment of polar pesticides in the Llobregat River Basin (NE Spain). Chemosphere 2012; 86: 8-16.

16. Kudsk P, Mathiassen KS. Joint action of amino acid biosynthesis-inhibiting herbicides. Weed Res 2004; 4: 313-22.
17. Mkandawire M, Dudel EG. Are Lemna spp. effective phytoremediation agents. Biorem Biodiv Bioavail 2007; 1(1): 56-71.

18. Mohammad M, Itoh K, Suyama K. Comparative effects of different families of herbicides on recovery potentials in Lemna sp. J Pestic Sci 2008; 33: 171-4.

19. Mohan BS, Hosetti BB. Aquatic plants for toxicity assessment. Envir Res A 1999; 81: 259-74.

20. OECD, 221. 2004. Guideline for the testing of chemicals. Lemna sp. Growth inhibition test.

21. Olette R, Couderchet M, Biagianti S, Eullaffroy $\mathrm{P}$. Toxicity and removal of pesticides by selected aquatic plants. Chemosphere 2008; 70: 1414-21.

22. Peterson HG, Boutin C, Martin P, Fremark KE, Ruecker NJ, Moody MJ. Aquatic phyto-toxicity of 23 pesticides applied at expected environmental concentrations. Aquat Toxicol 1994; 28: 275-92.

23. Riemens MM, Dueck T, Kempenaar C. Predicting sublethal effects of herbicides on terrestrial non-crop plant species in the field from greenhouse data. Envir Poll 2008; 155 : 141-9.

24. Ritz C, Streibig JC. Bioassay analysis using R. J Statis Software 2005; 12(5): 1-22.

25. Teodorović I, Knežević V, Tunić T, Čučak M, Nikolić Lečić J, Leovac A, Ivančev Tumbas I. Myriophyllum aquaticum versus Lemna minor: sensitivity and recovery potential after exposure to atrazine. Envir Toxic Chem 2012; 31: 417-26.

26. Turgut C, Grezichen A, Fomin A. Toxicity of sulfonylurea herbicides to dicotyledonous macrophyte Myriophyllum aquaticum in a 14 day bioassay. Fresen Envir Bull 2003; 12: 619-22.

27. Von Wettstein D. Chlorophyll-lethale und der submik roskopische Formwechsel der Plastiden. Exptl Cell Res 1957; 12: 427-506.

28. Žaltauskaitė J, Brazaitytė V. Assessment of the effects of sulfonylureas herbicide amidosulfuron application on target and non- 
target organisms. Fresen Envir Bull 2013; 22: 1977-82.

29. Wang M, Zhou Q. Effects of herbicide chlorimuron-ethyl on physiological mechanisms in wheat (Triticum aestivum). Ecotox Envir Safety 2006; 64: 190-7.

30. Wilson PC, Koch R. Influence of exposure concentration and duration on effects and recovery of Lemna minor exposed to the herbicide norflurazon. Arch Envn Contam Toxicol 2013; 64: 228-34.
Jūratė Žaltauskaitė, Roberta Norvilaitè

AMIDOSULFURONO (SULFONILURĖJŲ KLASĖS HERBICIDŲ) FITOTOKSIŠKUMAS VANDENS MAKROFITAMS LEMNA MINOR L.

\section{Santrauka}

Šio darbo tikslas buvo nustatyti sulfonilurèjų klasès herbicido Sekator OD 375 (amidosulfurono ir jodosulfurono) poveiki vandens augalui - mažajai plūdenai Lemna minor L. Augalai buvo paveikti 5-75 $\mu \mathrm{l} \mathrm{l}^{-1}$ herbicido koncentracijomis. Herbicidas pasižymėjo dideliu fitotoksiškumu L. minor L. (sumažèjo augimas ir biomasè, fotosintezès pigmentų kiekis ir padidèjo malondialdehido koncentracija). L. minor L. augimo greitis sumažejo 54,17 \%, sausoji biomasè sumažejo apie 57,2 \%. Herbicidas sukèlè oksidacinị stresą, MDA koncentracija paveiktose mažosiose plūdenose buvo 83,32 didesnè nei kontroliniuose augaluose.

Raktažodžiai: herbicidai, vandens augalai, oksidacinis stresas, fitotoksiškumas 
